\title{
Is Cell Therapy Promising or Lost in Translation in Patients With Acute Myocardial Infarction?
}

\author{
Yukihito Higashi, MD, PhD
}

$\mathbf{C}$ onventional therapy for acute myocardial infarction (AMI) is established. However, in some patients, AMI leads to cardiac dysfunction, resulting in an increase in mortality rate. Thus, therapeutic strategies to prevent severe cardiac dysfunction in patients with AMI must be established. Cell therapy is promising for restoration and maintenance of cardiac function in patients with AMI. Results of 10 pilot studies using cell therapy have so far been reported, and more than 20 clinical trials involving patients with AMI and congestive heart failure are ongoing. ${ }^{1}$ Unfortunately, not all studies have been equally positive; in some cases, there were no effects. ${ }^{2,3}$ In addition, the results of some studies using animal models have not supported the efficacy of cell therapy for AMI. ${ }^{4,5}$ Although clinical trials have shown no adverse effects during follow-up periods of $2-18$ months, some adverse effects, such as coronary restenosis and arrhythmia, have been described in case reports. ${ }^{1,6,7}$ Controversial results of clinical trials using cell therapy in patients with AMI might be due to different study protocols, including the transplanted cell source, number of cells, cell isolation, cell storage, cell delivery system, timing of cell administration, outcomes, and selection of patients.

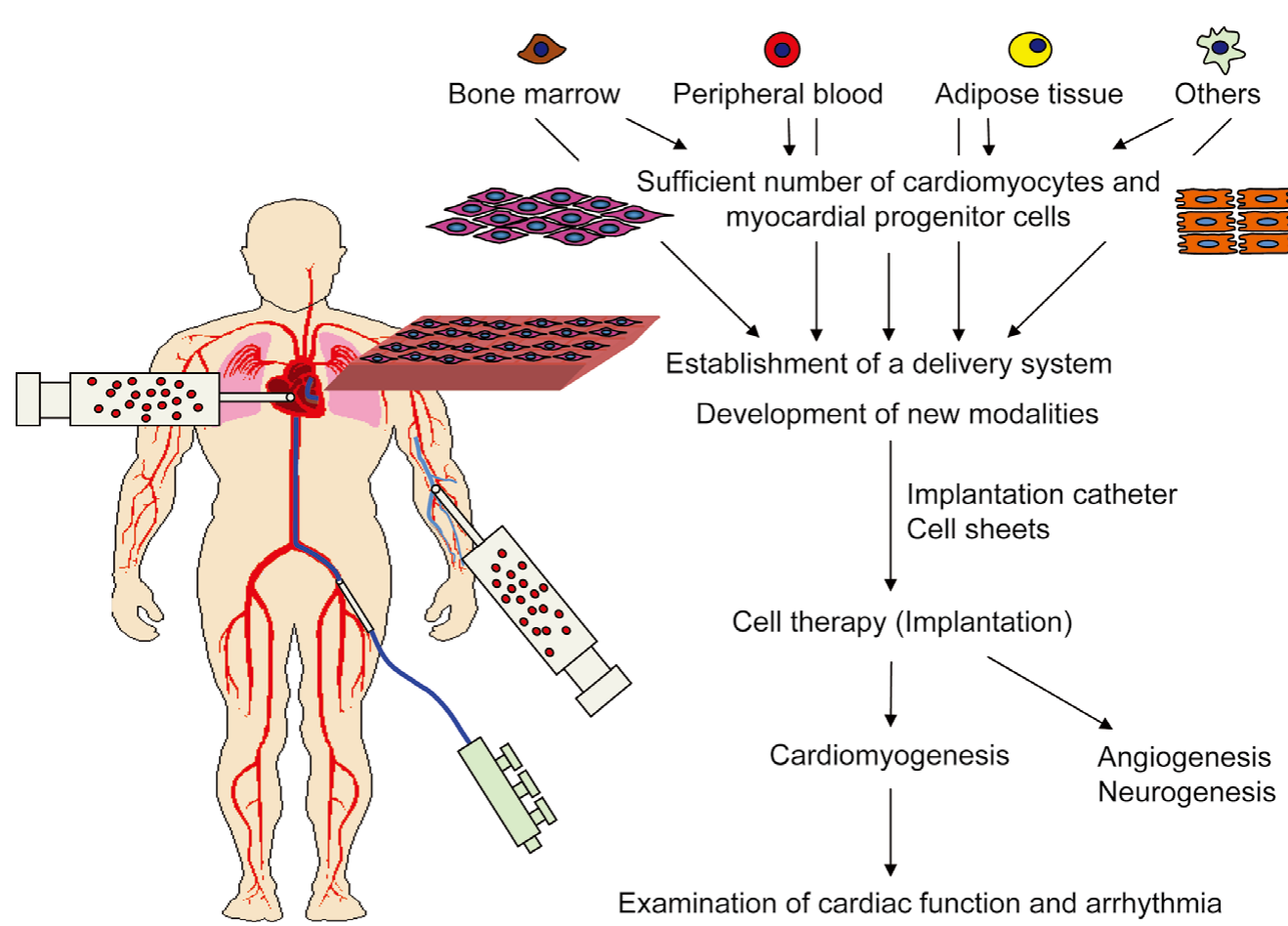

Figure. Ideal cell therapy and critical issues that remain to be resolved in acute myocardial infarction.

The opinions expressed in this article are not necessarily those of the editors or of the Japanese Circulation Society.

Received January 6, 2011; accepted January 6, 2011; released online January 27, 2011

Department of Cardiovascular Physiology and Medicine, Graduate School of Biomedical Sciences, Hiroshima University, Hiroshima; Division of Regeneration and Medicine, Hiroshima University Hospital, Hiroshima, Japan

Mailing address: Yukihito Higashi, MD, PhD, FAHA, Department of Cardiovascular Physiology and Medicine, Graduate School of Biomedical Sciences, Hiroshima University, Division of Regeneration and Medicine, Hiroshima University Hospital, 1-2-3 Kasumi, Minami-ku, Hiroshima 734-8551, Japan. E-mail: yhigashi@hiroshima-u.ac.jp

ISSN-1346-9843 doi:10.1253/circj.CJ-11-0017

All rights are reserved to the Japanese Circulation Society. For permissions, please e-mail: cj@j-circ.or.jp 


\section{Article p 683}

In this issue of the Journal, in the study by Turan et $a,^{8}$ the efficacy of an intracoronary administration of autologous freshly isolated bone-marrow mononuclear cells for left ventricular function in patients with AMI was confirmed. The method of cell isolation is one of the critical issues that should be resolved when optimal cell therapy is performed for AMI. It is expected that an increase in activity of isolated cell function and number of isolated cells might have beneficial effects on cardiac function and structure after cell therapy. Interestingly, the system for harvesting bone-marrow autologous cells used in the present study increased the yield of isolated bone-marrow cells compared with the yield obtained from the Ficoll isolation method, and isolated cells obtained by the harvest bone-marrow autologous cell system included much higher numbers of stem or progenitor cells (eg, CD34+ and $\mathrm{AC} 33^{+}$) and platelets than those obtained by using the Ficoll isolation method. Isolation time using the harvest device is relatively short. In addition, the advantage of cell isolation by the harvest bone-marrow system is not needed to require good manufacturing practice. Although fetal calf or bovine serum must be used in cell culture using previous cell isolation protocols, harvested bone-marrow cells are resuspended in the patient's autologous plasma, resulting in prevention of contamination. The harvest bone-marrow technique, rather than the Ficoll technique, might therefore be the best cell isolation system at present.

If we obtain an adequate cell isolation system, we will run head-on into a number of critical issues. Figure shows an algorithm for the ideal cell therapy and critical issues that remain to be resolved, including sources of transplanted cells (bone marrow-derived cells, hematopoetic stem cells, mesenchymal stem cells, adipose tissue-derived cells, skeletal myoblasts, and induced pluripotent stem cells, or induced cardiomyocytes and myocardial progenitor cells); sufficient number of transplanted cells; establishment of a cell delivery system (intracoronary, intravenous, and transmyocardial administration, and use of cell sheets); development of new modalities for cell delivery (cell implantation catheter and cell sheets); success of cardiomyogenesis; coexistence of angiogenesis and neurogenesis; and examination of cardiac function and arrhythmia. Another critical issue is that mechanisms by which cell therapy improves cardiac function and structure in patients with AMI remain unclear. It has been shown that transplanted adult stem cells die within 7 days after implantation and do not differentiate into cardiomyocytes in animal models of AMI.9,10 Stem or progenitor cells contain various growth factors and cytokines. ${ }^{11,12}$ Results of several studies support the concept that growth factors and cytokines released by implanted cells predominately contribute to the improvement in cardiac function through mobilization of various progenitor cells, including myocardial progenitor cells. ${ }^{13,14}$ However, it is unknown whether these mechanisms work in humans. Further studies are needed to elucidate the precise mechanism of cell therapy-induced improvement in cardiac function in patients with AMI. Finally, attention should be given to the safety of cell therapy, par- ticularly the risk of ventricular arrhythmia, acceleration of atherosclerosis, and canceration in long-term, follow-up periods. Until these critical issues have been addressed, it is unclear whether cell therapy is promising or lost in translation in patients with AMI.

To reach the complete goal of cell therapy for acute myocardial infraction, we must resolve critical issues and we still have a long way to go. "Rome was not built in a day."

\section{References}

1. Wollert KC, Drexler H. Cell therapy for the treatment of coronary heart disease: A critical appraisal. Nat Rev Cardiol 2010; 7: $204-$ 215.

2. Lunde K, Solheim S, Aakhus S, Arnesen H, Abdelnoor M, Egeland $\mathrm{T}$, et al. Intracoronary injection of mononuclear bone marrow cells in acute myocardial infarction. $N$ Engl J Med 2006; 355: 11991209.

3. Tendera M, Wojakowski W, Ruzyłło W, Chojnowska L, Kepka C, Tracz W, et al; REGENT Investigators. Intracoronary infusion of bone marrow-derived selected CD34+CXCR4+ cells and non-selected mononuclear cells in patients with acute STEMI and reduced left ventricular ejection fraction: Results of randomized, multicentre Myocardial Regeneration by Intracoronary Infusion of Selected Population of Stem Cells in Acute Myocardial Infarction (REGENT) Trial. Eur Heart J 2009; 30: 1313-1321.

4. Waksman R, Fournadjiev J, Baffour R, Pakala R, Hellinga D, Leborgne L, et al. Transepicardial autologous bone marrow-derived mononuclear cell therapy in a porcine model of chronically infarcted myocardium. Cardiovasc Radiat Med 2004; 5: 125-131.

5. Silva GV, Litovsky S, Assad JA, Sousa AL, Martin BJ, Vela D, et al. Mesenchymal stem cells differentiate into an endothelial phenotype, enhance vascular density, and improve heart function in a canine chronic ischemia model. Circulation 2005; 111: 150-156.

6. Kang HJ, Kim HS, Zhang SY, Park KW, Cho HJ, Koo BK, et al. Effects of intracoronary infusion of peripheral blood stem-cells mobilised with granulocyte-colony stimulating factor on left ventricular systolic function and restenosis after coronary stenting in myocardial infarction: The MAGIC cell randomised clinical trial. Lancet 2004; 363: 751-756.

7. Kolettis TM. Arrhythmogenesis after cell transplantation post-myocardial infarction: Four burning questions--and some answers. Cardiovasc Res 2006; 69: 299-301.

8. Turan RG, Bozdag-Turam I, Ortak J, Akin I, Kische S, Schneider $\mathrm{H}$, et al. Improvement of cardiac function by intracoronary freshly isolated bone marrow cells transplantation in patients with acute myocardial infarction. Circ J 2011; 75: 683-691.

9. Balsam LB, Wagers AJ, Christensen JL, Kofidis T, Weissman IL, Robbins RC. Haematopoietic stem cells adopt mature haematopoietic fates in ischaemic myocardium. Nature 2004; 428: 607-608.

10. Murry CE, Soonpaa MH, Reinecke H, Nakajima H, Nakajima HO, Rubart M, et al. Haematopoietic stem cells do not transdifferentiate into cardiac myocytes in myocardial infarcts. Nature 2004; 428: 664-668.

11. Rehman J, Li J, Orschell CM, March KL. Peripheral blood "endothelial progenitor cells" are derived from monocyte/macrophages and secrete angiogenic growth factors. Circulation 2003; 107: 11641169.

12. Kinnaird T, Stabile E, Burnett MS, Lee CW, Barr S, Fuchs S, et al. Marrow-derived stromal cells express genes encoding a broad spectrum of arteriogenic cytokines and promote in vitro and in vivo arteriogenesis through paracrine mechanisms. Circ Res 2004; 94: $678-685$.

13. Cho HJ, Lee N, Lee JY, Choi YJ, Ii M, Wecker A, et al. Role of host tissues for sustained humoral effects after endothelial progenitor cell transplantation into the ischemic heart. J Exp Med 2007; 204: 3257-3269.

14. Korf-Klingebiel M, Kempf T, Sauer T, Brinkmann E, Fischer P, Meyer GP, et al. Bone marrow cells are a rich source of growth factors and cytokines: Implications for cell therapy trials after myocardial infarction. Eur Heart J 2008; 29: 2851-2858. 